\title{
CORPORATE INCOME TAX BURDEN FOR SMES - THE CASE OF BOSNIA AND HERZEGOVINA
}

\begin{abstract}
Small and medium enterprises (SMEs) play a significant role in the economic development of both advanced and developing countries. Some earlier research showed that taxation and compliance costs have a significant effect on economic growth, development and performance of the business sector. For this reason, our research focuses on tax compliance costs imposed on the SMEs in Bosnia and Herzegovina $(B \& H)$, which is a transition and post-conflict country with a complex tax system structure. This complexity is particularly highlighted in the direct taxation system, hence the focus of this research is on corporate income tax (CIT) compliance costs. Our methodology is based on simulation of tax compliance costs between different entities in $B \& H$ - Federation of $B \& H(F B \& H)$ and the Republika Srpska (RS), as well as measuring the effective tax burden for SMEs in $B \& H$ and the region. Our simulation of the CIT return of a company , $X$ "in line with the entity law suggests that the effective tax burden is higher in RS than in FB\&H entity. This is further confirmed with the effective tax rate formula applied in the second part of the research using data from the AMADEUS database. This result has an important policy implication for the fiscal authorities in $B \& H$, as very often public discourse goes in the opposite direction to our finding.
\end{abstract}

Keywords: SME, corporate income tax, tax burden, tax compliance costs

JEL: H20, H25, H30, H32

\section{INTRODUCTION}

Taxation, regardless of collection type, represents the main source of revenue for most countries. For this reason, the developing political strategies to a large extent, are comprised of fiscal measures.

1 PhD student, University of Sarajevo, School of Economics and Business. E-mail: dipv@tcd.ie

2 Professor, University of Sarajevo, School of Economics and Business, E-mail: azra.hadziahmetovic@efsa.unsa.ba 
These strategies differ to some degree in terms of their structure, intent and target groups for which they are being designed, but the common thread is that they are designed to promote sustainable economic development. It is precisely because of this central motive that the countries strive towards creating attractive and competitive tax policies which most commonly include tax incentives, simplified tax procedures and last, but not least low tax rates. Such governmental efforts to differentiate and compete with others in order to attract capital resulted in a tax landscape suitable for tax (harmful) competition, which not only creates imbalance in the distribution of capital, but in many cases harms the small and medium enterprises which are frequently overlooked by the mentioned tax policies. This is particularly alarming considering that the SMEs generate about $90 \%$ of the economic activity worldwide. Their contribution to the economy is reason enough to analyse and capture the effects that the introduction of potential fiscal measures might have on this sector. These effects may be multiple (for example, administrative procedures, special tax schemes, etc.) and are mostly reflected in the tax compliance burden.

The corporate income tax ("CIT") component is of particular importance, not only for developing, but also for the developed countries, given the limited capacity of value-added taxation, the political sensitivity of personal income taxation, as well as the unused capacity of potential public revenue hidden in taxing corporate profits, and the underdeveloped laws regulating company taxation. For these reasons, the focus of this paper is CIT.

The shift in focus to the SME sector and the tax compliance costs arising for these companies has recorded a significant increase as countries turn more and more towards this sector. A study by European Commission in 2015 for example, was based on a premise that SMEs, in comparison to multinational enterprises, face significant tax compliance costs, i.e., costs arising out of complying with tax laws and regulations related to corporate income tax. For reasons of complexity and multi-layered administrative structures, simple logic dictates that these costs would be higher in countries that are administratively and politically divided, characterized by political tension, market insecurity and instability, as is the case of Bosnia and Herzegovina. For these reasons, the focus of this paper will be the example of Bosnia and Herzegovina, taking into account the complexity of the country's tax system, particularly in the context of corporate income taxation. Namely, the current fiscal structure of the country requires coordination, regulatory framework of indirect taxation to be implemented at the state level, while other direct taxes are implemented at the level of administrative and political entities. This direct tax system complexity is of particular importance when it comes to corporation taxes, which comprises three different CIT laws, three different tax administrations to implement these laws, which are further broken down into cantonal and/or municipal tax authorities, and three di- 
fferent tax returns. The complexity is galvanized for those companies operating and paying CIT in two or more administrative units. It is precisely this complexity that this paper focuses on the structure of CIT and the impact of such a structure on the Bosnian SMEs. The main intent of this paper is to measure the effective tax burden for SMEs in B\&H.

\section{Literature review}

The evolution of studying and measuring compliance costs is usually grouped either by geographic regions (USA, Europe, Asia, East Asia and Australia) or by phases. The first phase of studying this area began with the appearance of the first such studies in North America in the 1930s and 1960s, while the second phase saw this interest expand into Europe in the 1960s and 1970s. Phase three included the international spread of these studies. Most of the studies in the past and more recent times stem from the West, such as the region of North America (e.g., Blumenthal \& Slemrod, 1995; Vaillancourt, 1986; Sandford, 1989; Slemrod \& Venkatesh, 2002) and Europe (Allers 1994; Collard, et al., 1998; Diaz \& Delgado, 1995), Australia and New Zealand (Pope, et al., 1990; Pope et. al., 1991; Wallschutzky \& Gibson, 1993; Evans, et al., 1997; Sandford \& Hasseldine, 1992). A common thread of these studies is that they all tended to focus on SMEs in developed economies, while the study of tax compliance costs in transition economies has only recently recorded an increase. In the last decade, there has been research of tax compliance studies in countries such as Tanzania (Shekidele, 1999), Brasil (Bertolucci, 2002), India (Chattopadhyay \& Das-Gupta, 2002); Croatia (Blažić 2005); (Blažić \& Klun, 2005) and others. The challenge in researching transition economies lies in the lack of interest, unorganized and non-cooperative tax authorities as well as complex tax systems and regulations that are subject to frequent change, all of which adds to the increased complexity and consequently, higher tax compliance costs.

When it comes to measuring tax compliance costs, quantitative indicators prevail because of the ease of use and the possibility of formulating these in monetary of other terms. Thus, a majority of research on tax compliance costs uses time spent on monetary or financial units utilized in tax-related activities. Other, non-measuring, i.e., qualitative elements of the compliance costs, as mentioned, are avoided because of the lack of credible interpretation. Instead, studies that do use qualitative indicators tend to descriptively elaborate tax compliance costs. An example of this would be Pierpoint \& Auburn (1987) who attempt to offer a framework on researching the psychological component of factors that may predict these costs and their representation in different groups. 
There is a general consensus that tax compliance costs can be divided and measured in three different ways:

1. External costs, i.e., explicit costs measured through the monetary value of money paid to third parties (external consultants, tax authorities, etc.)

2. Internal costs, i.e., implicit costs, measured through employee utilized time on tax-related activities

3. Psychological costs measured through taxpayer stress, anxiety and frustration levels.

However, no matter the measurement method used, nearly all research on tax compliance costs indicate their regressive nature. In other words, the smaller the company, the higher the tax compliance costs. In effect, literature review in this area can be summarized as follows:

- Tax compliance costs are high and significant - most research shows that taxes imposed onto the taxpayers result in high costs, no matter the measurement method. These costs are linked to the most significant taxes and make up nearly $10 \%$ of the total company revenues (Klun, 2004:76).

- Tax compliance costs are regressive - Tax compliance costs are determined by company size. The reasons behind this repressiveness are twofold: diseconomies of scale for the SMEs and the fixed component of the tax expense (Evans, 2003).

- Tax compliance costs increase with tax system complexity - In countries with complex tax systems, the tax burden in terms of time spent increases by $39 \%$. In cases where two types of tax are under the jurisdiction of two tax authorities, the tax burden increases by $30 \%$ (Paying Taxes, 2014).

- Tax compliance costs comprise the most significant proportion of incurred costs - Research shows that external costs arising out of complying with tax codes are high for small companies, and that the tax element of such costs represents a significant burden.

- Tax compliance costs are higher than administration costs - research shows that administrative costs are lower and make up less than $1 \%$ of total generated revenues (Evans, 2003).

Following on from the above, it is reasonable to assume that tax compliance costs are high and negatively affect companies. Specifically, due to the capital limitations and lack of economies of scale, these costs particularly affect small companies. This effect is galvanized in transition economies where tax systems are complex, regulation unclear and tax code implementation is opaque. 
Taking into account the specific characteristic of transition economies, a high contribution of direct taxes, i.e., corporate income tax in total revenue, it is reasonable to assume that the tax compliance costs for these countries will stem from corporate income tax. Interestingly, while the number of studies researching tax compliance costs has increased in the transition and developing countries such as Malaysia and Tanzania, some of which focused on Western Balkans, none of these isolated or focused on the issue of corporate income taxation. Furthermore, no such research has been done to date for $\mathrm{B} \& \mathrm{H}$. When it comes to corporate income taxation, in the post-war period, only three elaborate studies in the area of direct taxation have come to light. Carsimamovic (2006) focused on ex- and post-ante tax rate burden of corporate income taxation, taking into account all companies, regardless of size, while Lazovic-Pita \& Pita (n/a) focused on the descriptive presentation of the direct tax system, with special attention paid to corporate income tax. Dzafic et al. (2011), on the other side, aimed at discovering general obstacles to SME development, and touched on taxation to some extent. -

\section{Research design and method}

This paper relies mainly on the use of verified secondary data sources. Firstly, secondary research comprised a literature review to provide context and show the need for this kind of research. Data collected in this manner related to the review of relevant tax theories, tax compliance costs as well as review of literature in terms of research results in an identical or similar field. Information was collected from a wide range of academic journals, books, official report and others. To ensure credibility and validity, the research comprised searching indexed academic journals such as Journal of Taxation, International Journal of Business and Management, National Tax Journal, and European Economic Review. For a book review, reputable publishers such as Wiley sons, Stanford University Press, Springer, and McGraw-Hill were selected. Official reports used in this paper were published by organisations such as the EBRD, OECD, USAID, IFC and IMF. Furthermore, this research is enriched by analysing the legal framework as well as the data available through the AMADEUS $^{3}$ database.

3 AMADEUS database contains comprehensive information on around 21 million companies across Europe. More information on https://www.bvdinfo.com/en-gb/our-products/data/international/ amadeus\#secondaryMenuAnchor0 
The aim of this paper is to measure the effective tax burden for SMEs in B\&H, by focusing on the following research questions:

1. What is the effective CIT tax burden difference for company „X“, operating in different entities of the country?

2. What is the effective CIT tax burden at the entity and state level as compared to the region?

In order to answer the research questions, this paper contains two research elements that require direct data analysis, as follows:

A. analysis of simulated differences in tax returns in accordance with entity laws, and

B. analysis of the effective tax burden for the SMEs in B\&H, and the region, on the basis of data procured via the AMADEUS data base.

\subsection{Analysis of simulated differences in tax returns}

A high-level analysis of the entity tax laws indicates several significant differences which lead to the conclusion that a company may have different tax effects depending on the entity in which it submits its corporate income tax return. Considering, for example, that the tax law in the RS does not allow the same incentives and tax-deductible expenses, it may be assumed that the tax burden for any company, may be higher in the RS than that in the FB\&H. The aim of this analysis is to show the differences in the entity laws, and thereby the tax burden, using a simulated tax

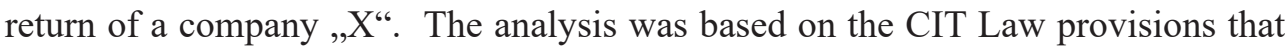
came into effect after 2017. In order to maintain consistency in numbers and allow for a better overview of figures, the assumption is made that both companies reported identical income statements ${ }^{4}$. Using uniform numbers and data means that all tax deductible and non-deductible expenses as per the entity legislations have been taken into account with the aim of identifying differences in taxable bases arising after corrections to accounting profits are made.

\subsection{Analysis of $\mathrm{SME}$ effective tax burden in $\mathrm{B} \& H$ and region}

In order to ensure the credibility of results, in addition to analysing tax returns, it is also necessary to make a conclusion on the effective tax burden for SMEs in the country by analysing financial data of real companies. To achieve this, financial data contained in the AMADEUS database was used.

4 Income statement shown in the appendix 
The significance of this database is demonstrated in access to financial data of companies registered worldwide, and the fact that it is the most reputable source for transfer pricing analyses. The data available through this database makes it possible to determine profit margins generated at arm's length as well as potential adjustments necessary to the taxable base.

The analysis of the effective tax burden for this paper will focus on SMEs registered in Serbia, Croatia, and Montenegro. Consistency of the collected data was ensured by using a uniform definition of SMEs based on EU recommendations, the legal form of a limited liability company as well as including only those SMEs of active legal status. The analysis covered over 30 thousand SMEs across the region, with the detailed per country breakdown shown in Table 1 below.

Table 1: Total population analysed for effective tax burden

\begin{tabular}{|l|r|}
\hline \multicolumn{1}{|c|}{ Per country/region } & \multicolumn{1}{c|}{ No. of SMEs } \\
\hline Bosnia and Herzegovina & 5,233 \\
\hline FB\&H & 3,680 \\
\hline RS & 1,553 \\
\hline Croatia & 11,056 \\
\hline Serbia & 12,918 \\
\hline Montenegro & 1,195 \\
\hline Total & $\mathbf{3 0 , 4 0 2}$ \\
\hline
\end{tabular}

Source: AMADEUS/ORBIS database, 2019

The tax burden is measured through the effective tax rate ${ }^{5}$ calculated as the percentage of corporate income tax in the total net earnings of the SME. The period to which the collected data pertains is tax years 2014-2018. In order to ensure the credibility of the results, the total population was adjusted to not include:

- Results where EBIT data is not available

- Results where tax cost data is not available

- Negative tax $\div$ EBIT percentages

Data was also adjusted for extreme results to achieve equal distribution, meaning that values above the 75th quartile and below the 25th quartile were eliminated from the final data. This method is commonly used in statistics to adjust the data set for outliers. Furthermore, this method is frequently applied in transfer pricing analysis to ensure minimal market data analysis distortions (e.g. Anderson et al., 2016).

5 Calculated as follows: tax costs / earnings before interest and tax (EBIT) - used to calculate tax rate because it does not include other tax types (such as VAT etc.) 


\section{Research results}

\subsection{Simulated differences in tax returns}

For the purposes of the analysis, let's imagine a company „X“ undertaking business activity in the FB\&H or RS and has reported trial balance numbers as presented in appendix 1 of this paper. Under the assumption that this company in the last five years (as allowed by law) reported no tax losses, nor had any paid advances, the tax return of company „X“ would be as presented in Tables 2 and 3 below. It is important to note that the simulated tax returns include adjustments that are likely to occur in most businesses' profit and loss accounts (salaries, entertainment costs, donations and receivables written-off), and which are similarly defined within the legal context of the entities. Thus, it may be expected that identified differences may be greater once real transactions and other items are taken into account, and that are treated differently by entity laws. Another point to note is that the industry sector may also play a role in determining the level of a burden since for example, manufacturing companies are allowed incentives relating to investment and equipment depreciation. Besides, companies that report significant receivables may have different tax burden in the FB\&H than those in the RS due to the different treatment of receivables written off as a deductible expense.

Table 2: Tax return simulations for Company „X“, in the FB\&H

\begin{tabular}{|l|r|}
\hline Item of the tax return & BAM \\
\hline Financial result as per Income Statement & 160,914 \\
\hline Business profits for the year & $\mathbf{1 6 0 , 9 1 4}$ \\
\hline Business result for the year & 15,726 \\
\hline Adjustments of expenses & 2,56 \\
\hline $\begin{array}{l}\text { Expenses for personal income of employees and other individuals paid out exceeding the tax-free } \\
\text { amount in accordance with the regulation }\end{array}$ & 18,385 \\
\hline $\begin{array}{l}\text { 70\% of entertainment expenses relating to business activities and total non-deductible entertainment } \\
\text { expenses }\end{array}$ & 3,923 \\
\hline $\begin{array}{l}\text { Donations for humanitarian, cultural, educational, scientific and sport purposes exceeding 3\% of total } \\
\text { revenue as well as total expenses for professional sports }\end{array}$ & 1,599 \\
\hline Sponsorship exceeding 2\% of total revenue & 42,194 \\
\hline Monetary fees and fines & 15,332 \\
\hline & 15,332 \\
\hline Adjustments of income & 187,775 \\
\hline Income from receivables settled but previously written off & \\
\hline & 0 \\
\hline Taxable income/loss for the period & 187,775 \\
\hline Taxable income & $\mathbf{1 8 7 , 7 7 5}$ \\
\hline Taxable base & $\mathbf{1 1 , 6 7 \%}$ \\
\hline Tax losses brought forward & \\
\hline Taxable base & \\
\hline CALCULATED TAX OBLIGATION, CREDITS AND REDUCTION OF TAX OBLIGATION \\
\hline Taxable base & \\
\hline Total tax due @ 10\% & \\
\hline & \\
\hline Effective tax rate & \\
\hline
\end{tabular}


Table 3: Tax return simulations for Company „X“, in the RS

\begin{tabular}{|c|c|}
\hline Item of the tax return - RS & BAM \\
\hline \multicolumn{2}{|l|}{ INCOME } \\
\hline Income from business activity & $1,053,554$ \\
\hline Total gross income & $1,053,554$ \\
\hline \multicolumn{2}{|l|}{ Business expenses } \\
\hline Material expenses & 6,375 \\
\hline Fuel and energy expenses & 8,26 \\
\hline Gross salaries and employee awards & 684,957 \\
\hline Expenses of repairs and maintenance & 4,5 \\
\hline Interest expense & 14,755 \\
\hline Depreciation expenses & 74,479 \\
\hline Other deductibles & 3 \\
\hline Total expenses & 796,326 \\
\hline \multicolumn{2}{|l|}{ TAX CALCULATION } \\
\hline Profit/loss & 257,228 \\
\hline Loss carried forward & 0 \\
\hline Taxable base & 257,228 \\
\hline Taxable base reductions & 0 \\
\hline Taxable base & 257,228 \\
\hline Tax amount@10\% & 25,723 \\
\hline Effective tax rate & $15,99 \%$ \\
\hline
\end{tabular}

As can be seen from the presented simulations, there are differences in the total amount of tax obligation due. Consequently, there are differences in the effective tax burden whereby the effective tax rate for the FB\&H is $11,67 \%$ while the same analysis for the RS shows a higher tax burden of $15.99 \%$.

\subsection{Effective tax burden in $B \& H$ and region}

As previously mentioned, in order to confirm the analysis of the simulated tax returns, it is necessary to replicate the research on real-life financial data. In line with this, the analysis was conducted on over 30 thousand SMEs in B\&H and the region using the financial data available through the AMADEUS database, as previously detailed in Table 1.

Database search criteria used are as follows:

- $<250$ employees (as per the EU SME definition)

- Total revenues $<$ EUR 50 million

- Total balance sheet $<$ EUR 43 million

- Companies for which CIT value and EBIT values are available 
As described previously, data was adjusted for extreme values in order to achieve normal distribution, and the effective tax burden ${ }^{6}$ was calculated using the formula (Lammersen, 2002):

\section{Tax $\div$ Earnings before interest and tax}

The formula used is an accounting formula widely used to calculate an effective tax rate for corporations. Analysing independently collected financial data of SMEs, based on the median, for effective tax burden showed Croatia to have the highest CIT burden of $19 \%$, while Montenegro has the lowest burden of about $8.36 \%$. The analysis of the tax burden at the country level for $\mathrm{B} \& \mathrm{H}$, generated an effective tax burden of $9.22 \%$, ranking it among the lowest in the region.

Figure 1: Effective tax burden in the region, 2014-2018

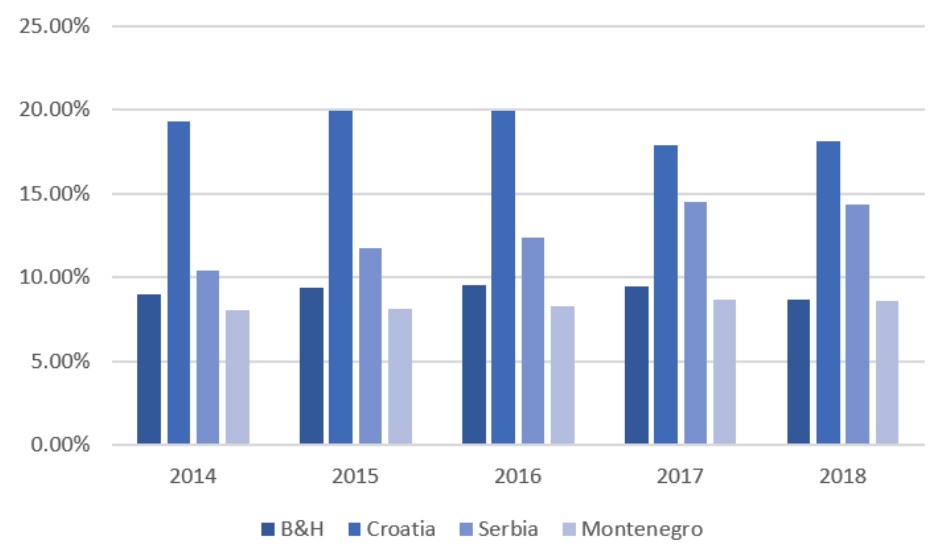

Source: AMADEUS/ORBIS database, 2019

Replicating the analysis approach at the level of the FB\&H and the RS, the results show a higher effective CIT burden for companies in the RS, which corroborates the results generated by the simulated tax return analysis. Analysis of previous year data, in the period stretch 2014-2018, the data shows a consistently higher burden in the RS. On average, the effective tax burden arising from CIT amounts to $9.77 \%$ in the RS and $9.45 \%$ in the FB\&H.

6 „An effective tax rate would be based not on taxable profit as defined by law but on an economic measure and thus would also consider the impact of the tax base" (Lammersen,L., (2002:8)). 
Figure 2: Effective CIT burden, entity comparison
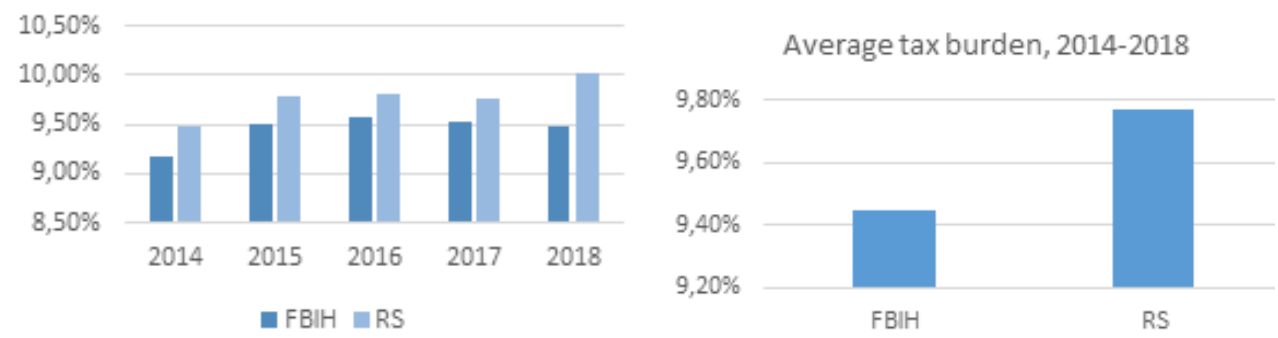

\section{CONCLUSION}

Bosnia and Herzegovina is a country characterized by a complex tax system comprised of multi-layered tax administrations, regulations and by-laws, particularly in relation to corporate income taxation. Given such a structure gives rise to unnecessary complexities for companies operating in the country, with the significant effect being directed at small and medium companies. Different CIT regulations enacted at the entity level in the country, in terms of tax-deductibility of costs, availability of tax incentives, etc. gives rise to varying degrees of severity of the tax burden. A high-level analysis of the legislation at the entity level indicated a higher CIT burden for companies registered and operating in the RS. Two-levelled research employed in this paper supported this proposition.

Firstly, a simulated tax return for an imaginary company " $X$ ", using uniform financial accounting figures, showed that the tax return prepared based on the RS CIT legislation yielded a higher tax burden, than that of the FB\&H. Secondly, a broader analysis, based on independently collected data from the AMADEUS database, again, showed a slightly higher effective tax burden for companies in the RS, than those in the FB\&H. Furthermore, the AMADEUS database analysis showed Bosnia and Herzegovina to be at the lower end of the tax-effective burden scale in the regional context. 


\section{REFERENCES}

1. Allers, M., 1994. Administrative and compliance costs of taxation and public transfers in the Netherlands. s.1.:Wolters-Noordhoff: Groeningen.

2. Anderson, D.R., Sweeney, D.J., Williams, T.A., 2016, Statistics for Business and Economics, Cengage Learning 2016

3. Bertolucci, A., 2002. The compliance costs of taxation in Brazil: a survey of costs in Brazilian Public Companies. s.1.:University of Sao Paoulo.

4. Blažić, H., 2005. Compliance costs of taxation in a transition country: the example of Croatia. s.1., National tax association proceedings, 97th Annual conference on taxation.

5. Blažić, H. \& Klun, M., 2005. Tax compliance costs for companies in Slovenia and Croatia. Finanzarchiv, 61(3), pp. 418-738.

6. Blumenthal, M. \& Slemrod, J., 1995. The compliance cost of taxing foreign-source income: Its magnitude, determinants, and policy implications. International Tax and Public Finance, Tom. 2, pp. 37-53.

7. Čaršimamović, N., 2006. Efektivno opterećenje poreza na dobti preduzeća u Bosni i Hercegovini u poređenju sa drugim zemljama. s.1.:Direkcija za ekonomsko planiranje Vijeća Ministara B\&H - DEP.

8. Chattopadhyay, S. \& Das-Gupta, A., 2002. The compliance costs of the personal income tax and its determinants. New Delhi: National Institute of Public Finance and Policy.

9. Collard, D., Green, S., Godwin, M. \& Maskell, L., 1998. The tax compliance costs for employers of PAYE and national insurance in 1995-96, London, Vol. 1: Main Report, Inland Revenue.

10. Džafić, Z., Zahirović, S., Okičić, J. \& Kozaric, A., 2011. Internal and external obstacles to the development of SMEs in Bosnia and Herzegovina. Croatian Economic Survey, 13(1), pp. 143-171.

11. Diaz, C. \& Delgado, M., 1995. The compliance costs of personal income tax in Spain. U: C. Sandford, ur. Taxation compliance costs measurement and policy. Bath: Fiscal Publications.

12. European Commission. 2015. SME taxation in Europe - an empirical study of applied CIT for SMEs compared to large enterprises, s.1.: European Commission. 
13. Evans, C., Ritchie, K., Tran-Nam, B., Walpole, M. 1997. A report into the incremental costs of taxpayer compliance. Canberra.:s.n.

14. Evans, C., 2003. Studying the studies: an overview of recent research into taxation operating costs. E-journal of tax research, Tom. 1, pp. 64-92.

15. Klun, M., 2004. Compliance costs for personal income tax in a transition country: the case of Slovenia. Fiscal Studies, 25(1), pp. 93-104.

16. Lazović-Pita, L. \& Pita, S., n/a. Poreski izdaci u sistemu poreza na dobit - primjer Bosne i Hercegovine. s.l.:Institut za javne finansije Hrvatske.

17. Lammersen, L.. 2002. The Measurement of Effective Tax Rates: Common Themes in Business Management and Economics. Discussion paper 02-46. Centre for European Economic Research.

18. Pope, J., Fayle, R. \& Chen, D., 1991. The compliance costs of public companies, Income taxation in Australia 1986/87. s.1.:s.n.

19. Pope, J., Fayle, R. \& Duncanson, M., 1990. The compliance costs of personal income taxation in Australia, 198687. Australian Tax Research Foundation.

20. Pierpoint, P. \& Auburn, T., 1987. The psychic costs of tax compliance: nature and implications for policy. s.1.:Documentos de Trabajo de la Facultad de Ciencias Economicas y Empresariales no.17.

21. Paying Taxes, 2014. Paying taxes 2014: the global picture, a comparison of tax systems in 189 economies worldwide, s.1.: World Bank \& PWC.

22. Sandford, C., 1989. What it costs to pay tax: policy issues. s.l.:Accountancy 113.

23. Slemrod, J. \& Venkatesh, V., 2002. The income tax compliance cost of large and mid-size businesses. s.1.:Ross School of Business Paper no. 914.

24. Sandford, C. T. \& Hasseldine, . J., 1992. The compliance costs of business taxes in New Zealand.. Wellington: Institute of Policy studies.

25. Shekidele, C., 1999. Measuring the compliance costs of taxation excise duties 1995-96. The African Journal of Finance and Management, 7(2), pp. 72-84.

26. Vaillancourt, F., 1986. The administrative compliance costs of the personal income tax and payroll tax system in Canada. Toronto: Canadian Tax Foundation.

27. Wallschutzky, I. \& Gibson, B., 1993. Small business cost of tax compliance. Australian Tax Forum, 10(4), pp. 511-543. 


\section{UNIVERSITY OF ZENICA FACULTY OF ECONOMICS}

Vernesa Lavić

Azra Hadžiahmetović

\section{PORESKO OPTEREĆENJE U MALIM I SREDNJIM PREDUZEĆIMA- SLUČAJ BOSNE I HERCEGOVINE}

\section{SAŽETAK:}

Mala i srednja preduzeća (MSP) igraju značajnu ulogu u ekonomskom razvoju razvijenih i zemalja u razvoju. Ranije istraživanje je pokazalo da troškovi oporezivanja i pridržavanja poreznih propisa u velikom dijelu utiču na ekonomski rast, razvoj $i$ performanse poslovnog sektora. Iz ovog razloga, naše istraživanje se fokusira na troškove oporezivanja sa kojima se suočavaju MSP u Bosni i Hercegovini (BiH), a koja je ujedno zemlja u tranziciji, te koja je pretrpjela ratna dejstva, a koja ima kompleksnu poreznu strukturu. Ova kompleksnost posebno je izražena u sistemu direktnog oporezivanja, pa je samim time i fokus ovog istraživanja porez na dobit. Naša metodologija zasniva se na simulaciji troškova oporezivanja, odnosno poreznog opterećenja, za preduzeće „X“ koje posluje u Federaciji BiH (FBiH) i entitetu Republika Srpska (RS). Simulacija poreznog bilansa u skladu sa entitetskim zakonima pokazala je da je ovo opterećenje više u RS nego je to slučaj u FBiH. Ovakav rezultat potvrdio je i drugi dio analize koji podrazumijeva mjerenje efektivnog poreznog opterećenja za MSP u BiH i regionu, na osnovu podataka AMADEUS baze podataka. Ovaj rezultat ima važne implikacije za donosioce zakona u smislu kreiranja fiskalnih politika u BiH, jer javni diskurs obično ide u suprotnosti s našim nalazima.

Ključne riječi: $M S P$, direktono oporezivanje, porez na dobit, troškovi oporezivanja JEL: H20, H25, H30, H32 


\section{APPENDICES}

\begin{tabular}{|c|c|c|c|}
\hline CLASS 5 -EXPENSES & BAM & BAM & \\
\hline \multicolumn{4}{|l|}{ Cost of material } \\
\hline Raw materials and spare parts & 6,375 & & \\
\hline Fuel and energy & 8,260 & & \\
\hline Small inventory write-off & 200 & & \\
\hline Total & & 14,835 & \\
\hline \multicolumn{4}{|c|}{ Cost of salaries and other employee expenses } \\
\hline Salaries & 670,868 & & \\
\hline Official travel & 17,322 & & \\
\hline Other employee payments & 5,493 & & \\
\hline Total & & 693,683 & \\
\hline \multicolumn{4}{|l|}{ Manufacturing related expenses } \\
\hline Transport & 7,000 & & \\
\hline Maintenance services & 4,500 & & \\
\hline Total & & 11,500 & \\
\hline \multicolumn{4}{|l|}{ Depreciation } \\
\hline Tax deductible depreciation & 74,479 & & \\
\hline Total & & 74,479 & \\
\hline \multicolumn{4}{|l|}{ Other expenses } \\
\hline Entertainment expenses & 2,560 & & \\
\hline Postage expenses & 950 & & \\
\hline Other miscellaneous expenses & 97 & & \\
\hline Sponsorships & 25,000 & & \\
\hline Scholarships & 3,000 & & \\
\hline Donations & 50,000 & & \\
\hline Monetary fees and fines & 1,599 & & \\
\hline Total & & 83,206 & \\
\hline \multicolumn{4}{|l|}{ Financial expenses } \\
\hline Interest & $14,754.92$ & & \\
\hline Exchange rate differences & 457.57 & & \\
\hline Total & & $15,212.49$ & \\
\hline Total expenses & & & $892,915.49$ \\
\hline CLASS 6 - INCOME & BAM & BAM & \\
\hline \multicolumn{4}{|l|}{ Income from sale of goods } \\
\hline Income from domestic sales & $1,009,856.13$ & & \\
\hline Income from foreign market sales & 28,366 & & \\
\hline Total & & $1,038,222.13$ & \\
\hline \multicolumn{4}{|l|}{ Financial income } \\
\hline Exchange rate differences & 275 & & \\
\hline Total & & 275 & \\
\hline \multicolumn{4}{|l|}{ Other income and deductibles } \\
\hline Receivables settled, previously written off & 15,332 & & \\
\hline Total & & 15,332 & \\
\hline Total income & & & $1,053,829.13$ \\
\hline Profit for the year & & & $160,913.64$ \\
\hline
\end{tabular}

